\title{
Nutrient digestion, microbial protein synthesis, and blood metabolites of Jersey heifers fed chitosan and whole raw soybeans
}

\author{
Jefferson Rodrigues Gandra', Caio Seiti Takiya², Euclides Reuter de Oliveira", Pablo Gomes \\ de Paiva ${ }^{3}$, Rafael Henrique de Tonissi e Buschinelli de Goes ${ }^{1}$, Érika Rosendo de Sena Gandra', \\ Hayne Mayumi Cariolano Araki ${ }^{1}$
}

\footnotetext{
${ }^{1}$ Universidade Federal da Grande Dourados, Faculdade de Ciências Agrárias, Dourados, MS, Brasil.

${ }^{2}$ Universidade de São Paulo, Faculdade de Medicina Veterinária e Zootecnia, Programa de Pós-graduação em Nutrição e Produção Animal, Pirassununga, SP, Brasil.

${ }^{3}$ Universidade Estadual Paulista "Julio de Mesquita Filho", Faculdade de Ciências Agrárias e Veterinárias, Programa de Pós-graduação em Zootecnia, Jaboticabal, SP, Brasil.
}

\begin{abstract}
This study was undertaken to determine the effects of chitosan and whole raw soybean on nutrient intake and total tract digestion, nitrogen utilization, microbial protein synthesis, blood metabolites, and energy balance of dairy heifers. Twelve Jersey heifers $(6 \pm 0.5$ months of age and $139.50 \pm 25.56 \mathrm{~kg}$ of live weight; mean \pm standard deviation $)$ were randomly assigned to a replicated Latin square design with a $2 \times 2$ factorial arrangement. The experimental period consisted of 14 days of adaptation to diets, six days of sampling, and five days of washout. The experimental diets were: control (CO);

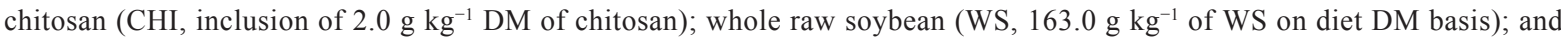
chitosan + whole raw soybean (CHI+WS). Chitosan decreased dry matter and neutral detergent fiber intakes; however, $\mathrm{CHI}$ increased DM total tract digestion. An interaction effect was observed on retained nitrogen, which increased when animals were fed $\mathrm{CHI}+$ WS compared with $\mathrm{CO}$ or CHI, but did not differ from that of animals fed WS. Chitosan decreased microbial nitrogen and crude protein flow of heifers. Energy balance was improved when heifers received diets containing WS. Efficiency of energy utilization was not affected by experimental diets. An interaction effect was observed for blood high-density lipoprotein (HDL) concentration, which increased with both dietary inclusion of CHI and WS compared with the other diets, and CHI provided the lowest value of HDL cholesterol. Chitosan and whole raw soybean do not alter nutrient intake and total tract digestion; however, they decrease nitrogen urinary excretion and increase blood HDL cholesterol of heifers.
\end{abstract}

Key Words: antimicrobial, nitrogen metabolism, oilseed, rumen modulator

\section{Introduction}

The rising feed costs and the necessity to improve the feed conversion ratio have increased the number of studies aimed at limiting the feed intake and increasing the dietary nutrient density (Hoffman et al., 2007). Whole raw soybean (WS) is commonly used as a source of supplementary fat and protein and is considered an economical and convenient source of nutrients (NRC, 2001). Furthermore, the lipid fraction contained in the WS is slowly released in the rumen environment due to the protein complex that protects the oil contained in the cotyledon of seeds, and consequently may not impair ruminal fiber digestion. In addition to the soybean availability, feeding WS decreases costs with taxes and fees

Received September 3, 2015 and accepted December 11, 2015

Corresponding author: jeffersongandra@ufgd.edu.br

http://dx.doi.org/10.1590/S1806-92902016000300007

Copyright (C) 2016 Sociedade Brasileira de Zootecnia. This is an Open Access article distributed under the terms of the Creative Commons Attribution License (http://creativecommons.org/licenses/by/4.0/), which permits unrestricted use, distribution, and reproduction in any medium, provided the original work is properly cited. and losses during the industrial process, transportation, and storage. To our knowledge, no studies with WS inclusion in the diet of dairy heifers are reported in literature. However, Venturelli et al. (2015) found that increasing dietary levels of WS decreased dry matter (DM) intake and maintained $3.5 \%$ fat-corrected milk yield of Holstein cows.

Another way to improve the performance of heifers is by using feed additives with antimicrobial activity to shift ruminal fermentation to a more energetically efficient pathway. Goiri et al. (2009) proposed the utilization of chitosan (CHI) to modulate ruminal fermentation and digestion with promising results. Chitosan is a natural biopolymer derived from the deacetylation of chitin (Goiri et al., 2009). The antimicrobial activity of CHI is well known against bacteria and fungi (Senel and McClure, 2004). However, the utilization of CHI in animal feeding has been underexploited, and there are few studies available in literature. Araújo et al. (2015) reported a linear increase in the digestibility of DM, crude protein (CP), and neutral detergent fiber (NDF) when beef steers were fed CHI, without changing their DM intake. 
The objective of the present experiment was to determine the effects of dietary inclusion of WS and CHI on nutrient intake and total tract digestion, nitrogen utilization, microbial protein synthesis, and blood metabolites of dairy heifers. Our hypothesis was that feeding both WS and CHI would improve nutrient total tract digestion and utilization by dairy heifers.

\section{Material and Methods}

This study was approved by the Bioethics Committee of Universidade Federal da Grande Dourados, located in Dourados - MS, Brazil. Twelve Jersey heifers $(6 \pm 0.5$ months of age and $139.50 \pm 25.56 \mathrm{~kg}$ of live weight; mean \pm standard deviation) were randomly assigned to a balanced (according to the body weight) and contemporary replicated Latin square design, with a $2 \times 2$ factorial dietary arrangement. The experimental periods consisted of 14 days of adaptation to diets, six days of sampling, and five days of washout. Animals were allocated in individual pens of $8 \mathrm{~m}^{2}$ throughout the experiment.

The following experimental diets were used: control (CO); chitosan (CHI, inclusion of $2.0 \mathrm{~g} \mathrm{~kg}^{-1} \mathrm{DM}$ of chitosan); whole raw soybean (WS, $163.0 \mathrm{~g} \mathrm{~kg}^{-1} \mathrm{DM}$ of WS); and chitosan + whole raw soybean (CHI+WS). The diets, formulated to provide an average daily gain of $700.0 \mathrm{~g} \mathrm{~d}^{-1}$ according to NRC (2001), were isonitrogenous and contained corn silage as the forage source (Table 1). Chitosan presented the following technical specifications: apparent density of $0.64 \mathrm{~g} \mathrm{~mL}^{-1}, 20 \mathrm{~g} \mathrm{~kg}^{-1}$ of ash, 7.0-9.0 of $\mathrm{pH}$, viscosity $<200 \mathrm{cPs}$, and deacetylation level of $95 \%$ (Polymar Industria e Cia. Imp. and Exp. Ltda., Ceara, Brazil). Diets were fed as a total mixed ration twice daily at $06.30 \mathrm{~h}$ and at $13.00 \mathrm{~h}$. Amounts of feed offered and orts for each heifer were weighed daily and orts were restricted to 5 to $10 \%$ of intake on an as-fed basis.

Samples of all diet ingredients $(0.5 \mathrm{~kg})$ and orts $\left(125.0 \mathrm{~g} \mathrm{~kg}^{-1}\right.$ of total daily orts) from each heifer were collected during the last six days of each period and combined into one composite sample of orts for each cow and one composite sample of silage. Samples were analyzed to determine dry matter (DM), crude protein (CP), ether extract (EE), neutral detergent fiber (NDF), acid detergent fiber, lignin, and ash according to AOAC (2000). Total feces collection was performed for a 24-h period on days 15, 16, and 17 of each experimental period from each heifer, and then feces were homogenized and aliquots of $10 \%$ (wet basis) were frozen at $-20{ }^{\circ} \mathrm{C}$ until analyses.

Urine samples were collected from each heifer $4 \mathrm{~h}$ after feeding on day 14 of each experimental period. The urine was filtered and $10 \mathrm{~mL}$ aliquots were immediately diluted in $40 \mathrm{~mL}$ of sulfuric acid $(0.036 \mathrm{~N})$ to prevent the bacterial destruction of purine derivatives and uric acid precipitation. A $50 \mathrm{~mL}$ urine sample with $1 \mathrm{~mL}$ of sulfuric acid $(0.036 \mathrm{~N})$ was stored for nitrogen, urea, and creatinine determination. Creatinine concentrations were determined by the enzymatic colorimetric method using commercial kits $\left(\right.$ Laborlab $^{\circledR}$, Osasco, Brazil) and reading was performed in an automatic biochemistry analyzer (SBA200 automatic biochemistry, CELM $^{\circledR}$, Sao Caetano do Sul, Brazil). The allantoin and uric acid concentrations in urine were determined by the colorimetric method according to the methodology of Fujihara et al. (1987), described by Chen and Gomes (1992). Total daily urinary volume was estimated as the ratio between creatinine excretion and creatinine concentration contained in the spot urine sample, according to Oliveira et al. (2001).

Samples of ingredients were analyzed in a bomb calorimeter to obtain the gross energy intake and calculate the energy efficiency, according to Harvatine and Allen (2006). Digestible energy intake was obtained based on the digestibility coefficient of experimental diets and gross energy intake, according to the energy values obtained for

Table 1 - Ingredients and chemical composition of the experimental diets

\begin{tabular}{|c|c|c|c|c|}
\hline \multirow{2}{*}{ Item } & \multicolumn{4}{|c|}{$\operatorname{Diet}^{1}$} \\
\hline & $\mathrm{CO}$ & $\mathrm{CHI}$ & WS & $\mathrm{CHI}+\mathrm{WS}$ \\
\hline \multicolumn{5}{|l|}{ Ingredient ( $\left.\mathrm{g} \mathrm{kg}^{-1} \mathrm{DM}\right)$} \\
\hline Corn silage & 500.4 & 500.4 & 500.4 & 500.4 \\
\hline Ground corn & 248.4 & 248.4 & 195.0 & 195.0 \\
\hline Soybean meal & 200.1 & 200.1 & 90.5 & 90.5 \\
\hline Whole raw soybean & - & - & 163.0 & 163.0 \\
\hline Mineral mixture ${ }^{2}$ & 51.1 & 51.1 & 51.1 & 51.1 \\
\hline Chitosan & - & 2.0 & - & 2.0 \\
\hline \multicolumn{5}{|c|}{ Chemical composition ( $\left.\mathrm{g} \mathrm{kg}^{-1} \mathrm{DM}\right)$} \\
\hline Dry matter, as-fed & 573.0 & 573.0 & 575.5 & 575.5 \\
\hline Organic matter & 950.3 & 950.3 & 948.2 & 948.2 \\
\hline Crude protein & 149.5 & 149.5 & 149.0 & 149.0 \\
\hline Ether extract & 24.8 & 24.8 & 72.0 & 72.0 \\
\hline Neutral detergent fiber & 378.3 & 378.3 & 383.8 & 383.8 \\
\hline Non-fiber carbohydrates ${ }^{3}$ & 397.7 & 397.7 & 336.9 & 336.9 \\
\hline Ash & 49.3 & 49.3 & 51.4 & 51.4 \\
\hline Total digestible nutrients ${ }^{4}$ & 710.0 & 710.0 & 774.3 & 774.3 \\
\hline Net energy ${ }^{4}$ & 1.62 & 1.62 & 1.78 & 1.78 \\
\hline Net energy for gain ${ }^{4}$ & 1.20 & 1.20 & 1.39 & 1.39 \\
\hline
\end{tabular}

DM - dry matter; EE - ether extract; NFC - non-fiber carbohydrates; CP - crude protein; NDF - neutral detergent fiber.

${ }^{1} \mathrm{CO}$ - control; CHI - chitosan, addition of $2 \mathrm{~g} \mathrm{~kg}^{-1}$ diet DM of chitosan; WS - whole raw soybeans, diet containing $72 \mathrm{~g} \mathrm{~kg}^{-1} \mathrm{EE}$ on diet DM basis; $\mathrm{CHI}+\mathrm{WS}$ - chitosan and whole raw soybeans, addition of $2 \mathrm{~g} \mathrm{~kg}^{-1}$ diet DM of chitosan and diet containing $72 \mathrm{~g} \mathrm{~kg}^{-1} \mathrm{EE}$.

${ }^{2}$ Contains per kilogram: 120.00 g Ca; 88.00 g P; $75.00 \mathrm{mg} \mathrm{I} ; 1,300.00 \mathrm{mg} \mathrm{Mn}$; $126.00 \mathrm{~g} \mathrm{Na} ; 15.00 \mathrm{mg} \mathrm{Se} ; 12.00 \mathrm{mg} \mathrm{S} ; 3,630.00 \mathrm{mg} \mathrm{Co} ; 55.50 \mathrm{mg} \mathrm{Cu}$; and $1,800.00 \mathrm{mg} \mathrm{Fe}$.

${ }^{3} \mathrm{NFC}=100-[(\% \mathrm{CP}-\% \mathrm{CP}$ from urea $+\%$ urea $)+\% \mathrm{EE}+\% \mathrm{ash}+\% \mathrm{NDF}]$, according to Hall (1998).

${ }^{4}$ Calculated according to the NRC (2001) model. 
the ingredients (Harvatine and Allen, 2006). The values of net energy intake, net energy for gain, and net energy for maintenance were calculated according to NRC (2001). At the start of experiment and on day 15 of each period, animals were weighed on a livestock scale for large animals.

Total excretion of purine derivatives was calculated as the sum of allantoin and uric acid excreted in urine, expressed in mol day ${ }^{-1}$. The absorbed microbial purines (Pabs, mmol d $\mathrm{d}^{-1}$ ) were calculated from the excretion of purine derivatives (PD, mmol/day) based on the following equation: $\mathrm{Pabs}=\left(\mathrm{PD}-0.512 * \mathrm{LW}^{0.75}\right) / 0.70$, in which 0.70 is the recovery of absorbed purines as purine derivatives and $0.512 * \mathrm{LW}^{0.75}$ is the endogenous excretion of purine derivatives (González-Ronquillo et al., 2003). Ruminal synthesis of nitrogenous compounds (Nmic, $\mathrm{g} \mathrm{N} \mathrm{d}^{-1}$ ) was calculated based on absorbed purines (Pabs, mmol d ${ }^{-1}$ ), using the following equation (Chen and Gomes, 1992): Nmic $=(70 * \mathrm{Pabs}) /(0.83 * 0.134 * 1000)$, in which 70 is the nitrogen content in purines $\left(\mathrm{mg} \mathrm{N} \mathrm{mol}^{-1}\right)$; 0.134 is the $\mathrm{N}$ from purine:total bacterial $\mathrm{N}$ ratio (Valadares et al., 1999); and 0.83 is the intestinal digestibility of microbial purines. Nitrogen balance was estimated by subtracting fecal and urinary nitrogen values from total nitrogen intake.

Blood samples were collected from all heifers in sterile Vacutainer ${ }^{\circledR}$ tubes by puncture of the coccygeal vein on day 14 of each experimental period, before the morning feeding. Blood samples were immediately centrifuged for $15 \mathrm{~min}$ at $2000 \times g$, and the supernatant was transferred to labeled plastic tubes and stored at $-20^{\circ} \mathrm{C}$. Creatinine and urea concentrations in the blood were determined by the colorimetric method using commercial kits (Laborlab ${ }^{\circledR}$, Osasco, Brazil). The plasma urea nitrogen concentration was obtained as the urea blood concentration multiplied by $0.466(\mathrm{~N}$ content of urea). Plasma creatinine nitrogen concentration was obtained by multiplying the concentration of creatinine in the plasma by 0.3715 ( $\mathrm{N}$ content of creatinine). The plasma depuration or clearance of creatinine and urea was obtained as the ratio between the urinary excretion for $24 \mathrm{~h}$ and the plasma concentration of each substance. The excreted fraction of urea was determined as the ratio between the depurations of plasma urea and creatinine.

Data were subjected to analysis of variance using the PROC MIXED procedure of SAS (Statistical Analysis System, version 9.1.3), checking the normality of residuals and homogeneity of variances using PROC UNIVARIATE procedure, according to the following model:

$$
\mathrm{Y}_{\mathrm{ijkl}}=\mu+\mathrm{a}_{\mathrm{i}}+\mathrm{P}_{\mathrm{j}}+\mathrm{C}_{\mathrm{k}}+\mathrm{W}_{\mathrm{l}}+\mathrm{C}_{\mathrm{k}} \mathrm{W}_{1}+\mathrm{P}_{\mathrm{j}} \mathrm{C}_{\mathrm{k}}+\mathrm{P}_{\mathrm{j}} \mathrm{W}_{\mathrm{k}}+\mathrm{e}_{\mathrm{ijk} \mathrm{l}} \text {, }
$$

in which: $Y_{i j k l}$ dependent variable; $\mu=$ overall mean; $a_{i}=$ animal effect; $\mathrm{P}_{\mathrm{j}}=$ fixed effect of period; $\mathrm{C}_{\mathrm{k}}=$ fixed effect of chitosan; $\mathrm{W}_{1}=$ fixed effect of whole raw soybean;
$\mathrm{C}_{\mathrm{k}} \mathrm{W}_{1}=$ chitosan*whole raw soybean interaction fixed effect; $\mathrm{P}_{\mathrm{j}} \mathrm{C}_{\mathrm{k}}=$ period*chitosan interaction fixed effect; $\mathrm{P}_{\mathrm{j}} \mathrm{W}_{\mathrm{k}}=$ period*whole raw soybean fixed effect; and $\mathrm{e}_{\mathrm{ijkl}}=$ residual error. The degrees of freedom were calculated as $\mathrm{DDFM}=\mathrm{kr}$. Significance level was set at 0.05 . The PDIFF test was applied when an interaction effect was observed to determine differences among treatments.

\section{Results}

As expected, control and $\mathrm{CHI}$ diets showed a higher non-fiber carbohydrate (NFC) content and lower total digestible nutrients (TDN) compared with diets containing WS. Ether extract content in fat-supplemented diets was $72 \mathrm{~g} \mathrm{~kg}^{-1}$ (Table 1).

Chitosan decreased $(\mathrm{P} \leq 0.022) \mathrm{DM}$ and NDF intake (Table 2). In addition, $\mathrm{CHI}$ increased $(\mathrm{P}=0.001) \mathrm{DM}$ total tract digestion. Whole raw soybean decreased $(\mathrm{P}=0.001)$ NFC intake and increased ether extract intake $(\mathrm{P}=0.001)$. Moreover, WS increased EE total tract digestion $(\mathrm{P}=0.012)$. No interaction effects were observed on nutrient intake and total tract digestion. Chitosan decreased $(\mathrm{P}=0.005)$ fecal nitrogen excretion (Table 3). An interaction effect $(\mathrm{P}=0.004)$ was observed on nitrogen excretion in urine, which was lower when heifers were fed chitosan associated with supplemental fat compared with $\mathrm{CO}$ or $\mathrm{CHI}$, but did not differ from animals fed WS. Furthermore, an interaction effect was observed on retained nitrogen, which increased when animals were fed CHI+WS compared with those fed $\mathrm{CO}$ or CHI, but did not differ from that of animals fed WS.

Gross energy, metabolizable energy, and net energy intake were higher $(\mathrm{P} \leq 0.033)$ in heifers fed WS compared with the other experimental diets. Energy balance was improved when heifers received diet containing WS ( $\mathrm{P}=$ 0.002). Efficiency of energy utilization was not affected by experimental diets.

Chitosan decreased $(\mathrm{P} \leq 0.023)$ total purine daily production, absorbable purines, microbial nitrogen, and crude protein flow of heifers (Table 4). Supplemental fat did not alter microbial protein synthesis of dairy heifers. An interaction effect $(P=0.024)$ was observed on uric acid, which increased when heifers were fed CHI+WS in relation to those fed $\mathrm{CO}$ or WS; animals fed $\mathrm{CHI}$ presented the lowest value of uric acid.

No interaction effects were observed on nitrogen compounds of heifers. However, CHI decreased $(\mathrm{P}=0.023)$ blood urea and urea nitrogen concentrations, and increased $(\mathrm{P}=0.008)$ blood creatinine and creatinine nitrogen concentrations (Table 5). Chitosan also decreased $(\mathrm{P}=0.009)$ creatinine clearance and increased $(\mathrm{P}=0.003)$ the 
fractional excretion of urea. Whole raw soybean increased $(\mathrm{P}=0.001)$ blood urea and decreased $(\mathrm{P}=0.012)$ creatinine concentrations. Consequently, WS decreased $(\mathrm{P}=0.001)$ urea clearance and increased $(\mathrm{P}=0.027)$ creatinine clearance.

Chitosan decreased $(\mathrm{P} \leq 0.002)$ total and low-density lipoprotein (LDL) cholesterol (Table 6), contrary to WS, which increased $(\mathrm{P} \leq 0.004)$ total and LDL cholesterol concentrations in blood. An interaction effect $(\mathrm{P}=0.006)$ was observed for blood high-density lipoprotein (HDL) concentration, which increased with both dietary inclusion of chitosan and WS compared with the other diets. Animals fed chitosan showed the lowest value of HDL cholesterol.

Table 2 - Nutrient intake and total tract digestion of Jersey heifers fed chitosan and whole raw soybeans

\begin{tabular}{|c|c|c|c|c|c|c|c|c|}
\hline \multirow{2}{*}{ Item } & \multicolumn{4}{|c|}{ Diet $^{1}$} & \multirow{2}{*}{ SEM } & \multicolumn{3}{|c|}{ P-value ${ }^{2}$} \\
\hline & $\mathrm{CO}$ & $\mathrm{CHI}$ & WS & $\mathrm{CHI}+\mathrm{WS}$ & & $\mathrm{CHI}$ & WS & INT \\
\hline \multicolumn{9}{|l|}{ Intake $\left(\mathrm{kg} \mathrm{d}^{-1}\right)$} \\
\hline Dry matter & 6.45 & 5.66 & 5.97 & 5.86 & 0.20 & 0.022 & 0.186 & 0.198 \\
\hline Crude protein & 1.06 & 1.00 & 0.99 & 1.00 & 0.03 & 0.678 & 0.277 & 0.118 \\
\hline Neutral detergent fiber & 2.21 & 1.90 & 2.05 & 1.92 & 0.07 & 0.009 & 0.222 & 0.177 \\
\hline Non-fiber carbohydrate & 2.75 & 2.57 & 2.16 & 2.18 & 0.09 & 0.167 & 0.001 & 0.225 \\
\hline \multicolumn{9}{|l|}{ Intake $(\mathrm{kg} / 100 \mathrm{~kg}$ of $\mathrm{LW})$} \\
\hline Dry matter & 4.50 & 4.07 & 3.55 & 3.45 & 0.11 & 0.100 & 0.001 & 0.208 \\
\hline Neutral detergent fiber & 1.92 & 1.78 & 1.29 & 1.28 & 0.06 & 0.178 & 0.001 & 0.308 \\
\hline \multicolumn{9}{|l|}{ Total tract digestion $\left(\mathrm{g} \mathrm{kg}^{-1}\right)$} \\
\hline Dry matter & 677.3 & 692.0 & 580.1 & 583.4 & 1.59 & 0.001 & 0.572 & 0.770 \\
\hline Organic matter & 698.7 & 709.9 & 615.9 & 618.6 & 1.45 & 0.006 & 0.665 & 0.751 \\
\hline
\end{tabular}

SEM - standard error of the mean; LW - live weight; DM - dry matter; EE - ether extract.

${ }^{1} \mathrm{CO}$ - control; CHI - chitosan, addition of $2 \mathrm{~g} \mathrm{~kg}^{-1}$ diet DM of chitosan; WS - whole raw soybeans, diet containing $72 \mathrm{~g} \mathrm{~kg}{ }^{-1} \mathrm{EE}$ on diet DM basis; CHI+WS - chitosan and whole raw soybeans, addition of $2 \mathrm{~g} \mathrm{~kg}^{-1}$ diet DM of chitosan and diet containing $72 \mathrm{~g} \mathrm{~kg}^{-1} \mathrm{EE}$.

${ }^{2}$ Effects of chitosan (CHI), whole raw soybeans (WS), and interaction between CHI and WS (INT).

Table 3 - Efficiency of nitrogen and energy utilization by Jersey heifers fed chitosan and whole raw soybeans

\begin{tabular}{|c|c|c|c|c|c|c|c|c|}
\hline \multirow{2}{*}{ Item } & \multicolumn{4}{|c|}{$\operatorname{Diet}^{1}$} & \multirow{2}{*}{ SEM } & \multicolumn{3}{|c|}{ P-value ${ }^{2}$} \\
\hline & $\mathrm{CO}$ & $\mathrm{CHI}$ & WS & $\mathrm{CHI}+\mathrm{WS}$ & & $\mathrm{CHI}$ & WS & INT \\
\hline \multicolumn{9}{|l|}{ Nitrogen balance $\left(\mathrm{g} \mathrm{d}^{-1}\right)$} \\
\hline $\mathrm{N}$ intake & 169.49 & 160.64 & 158.15 & 160.27 & 5.56 & 0.341 & 0.216 & 0.188 \\
\hline $\mathrm{N}$ feces & 40.02 & 36.62 & 38.69 & 37.87 & 1.66 & 0.005 & 0.546 & 0.504 \\
\hline $\mathrm{N}$ urine & $100.75 \mathrm{a}$ & $99.21 \mathrm{a}$ & $33.69 \mathrm{~b}$ & $30.35 b$ & 13.59 & 0.022 & 0.001 & 0.004 \\
\hline $\mathrm{N}$ absorbed & 129.47 & 124.02 & 119.45 & 122.40 & 5.21 & 0.148 & 0.342 & 0.323 \\
\hline $\mathrm{N}$ retained & $28.71 b$ & $24.80 \mathrm{~b}$ & $85.76 \mathrm{a}$ & $92.03 \mathrm{a}$ & 15.24 & 0.001 & 0.016 & 0.005 \\
\hline \multicolumn{9}{|l|}{ Intake (Mcal d $\left.{ }^{-1}\right)$} \\
\hline Gross energy & 26.95 & 25.95 & 29.79 & 29.47 & 0.98 & 0.096 & 0.008 & 0.182 \\
\hline Digestible energy & 20.91 & 19.25 & 21.28 & 21.05 & 0.70 & 0.087 & 0.091 & 0.189 \\
\hline Metabolizable energy & 18.25 & 16.84 & 18.84 & 18.68 & 0.62 & 0.200 & 0.033 & 0.289 \\
\hline Net energy & 8.37 & 7.83 & 9.06 & 9.08 & 0.30 & 0.252 & 0.003 & 0.186 \\
\hline \multicolumn{9}{|l|}{ Production (Mcal d ${ }^{-1}$ ) } \\
\hline Maintenance & 3.56 & 3.51 & 3.56 & 3.57 & 0.11 & 0.547 & 0.155 & 0.189 \\
\hline Growth & 2.25 & 2.25 & 2.26 & 2.26 & 0.07 & 0.814 & 0.871 & 0.957 \\
\hline Balance $\left(\right.$ Mcal d $\left.^{-1}\right)$ & 2.55 & 2.06 & 3.23 & 3.26 & 0.19 & 0.217 & 0.002 & 0.135 \\
\hline \multicolumn{9}{|c|}{ Efficiency of energy utilization (\%) } \\
\hline $\mathrm{NE}_{\mathrm{g}} / \mathrm{DE}$ & 10.93 & 11.73 & 10.63 & 10.76 & 0.25 & 0.139 & 0.115 & 0.263 \\
\hline $\mathrm{NE}_{\mathrm{m}}^{\mathrm{g}}+\mathrm{NE}_{\mathrm{g}} / \mathrm{DE}$ & 28.25 & 30.10 & 27.48 & 27.83 & 0.65 & 0.189 & 0.150 & 0.377 \\
\hline
\end{tabular}

SEM - standard error of the mean; DM - dry matter; EE - ether extract.

$\mathrm{NE}_{\mathrm{g}}$ - net energy for gain; $\mathrm{DE}$ - digestible energy; $\mathrm{NE}_{\mathrm{m}}$ - met energy for maintenance.

${ }^{1} \mathrm{CO}$ - control; CHI - chitosan, addition of $2 \mathrm{~g} \mathrm{~kg}^{-1}$ diet DM of chitosan; WS - whole raw soybeans, diet containing $72 \mathrm{~g} \mathrm{~kg}^{-1} \mathrm{EE}$ on diet DM basis; CHI+WS - chitosan and whole raw soybeans, addition of $2 \mathrm{~g} \mathrm{~kg}^{-1}$ diet DM of chitosan and diet containing $72 \mathrm{~g} \mathrm{~kg}^{-1} \mathrm{EE}$.

2 Effects of chitosan (CHI), whole raw soybeans (WS), and interaction between CHI and WS (INT).

$\mathrm{a}-\mathrm{c}$ - values in the same row with a different letter differ significantly at $\mathrm{P} \leq 0.05$ according to the PDIFF test. 
Table 4 - Microbial protein synthesis of Jersey heifers fed chitosan and whole raw soybeans

\begin{tabular}{|c|c|c|c|c|c|c|c|c|}
\hline \multirow{2}{*}{ Item } & \multicolumn{4}{|c|}{ Diet $^{1}$} & \multirow{2}{*}{ SEM } & \multicolumn{3}{|c|}{ P-value ${ }^{2}$} \\
\hline & $\mathrm{CO}$ & $\mathrm{CHI}$ & WS & $\mathrm{CHI}+\mathrm{WS}$ & & $\mathrm{CHI}$ & WS & INT \\
\hline Allantoin $\left(\mathrm{mmol} \mathrm{L}^{-1}\right)$ & 5.81 & 5.01 & 4.67 & 4.58 & 0.43 & 0.440 & 0.165 & 0.426 \\
\hline Total purines $\left(\mathrm{mmol} \mathrm{L}^{-1}\right)$ & 8.64 & 6.76 & 6.90 & 7.71 & 0.49 & 0.547 & 0.441 & 0.059 \\
\hline Allantoin $\left(\mathrm{mmol} \mathrm{d}^{-1}\right)$ & 84.09 & 64.23 & 84.78 & 59.19 & 7.56 & 0.055 & 0.668 & 0.775 \\
\hline Uric acid $\left(\mathrm{mmol} \mathrm{d}^{-1}\right)$ & 38.24 & 20.28 & 44.71 & 39.88 & 4.28 & 0.096 & 0.113 & 0.229 \\
\hline Total purines $\left(\mathrm{mmol} \mathrm{d}^{-1}\right)$ & 122.33 & 84.51 & 129.48 & 99.07 & 8.92 & 0.013 & 0.378 & 0.773 \\
\hline \multicolumn{9}{|l|}{ Microbial flow } \\
\hline Nitrogen $\left(\mathrm{g} \mathrm{d}^{-1}\right)$ & 103.86 & 71.09 & 110.00 & 83.71 & 7.74 & 0.023 & 0.445 & 0.678 \\
\hline Crude protein $\left(\mathrm{g} \mathrm{d}^{-1}\right)$ & 649.12 & 444.33 & 687.52 & 523.18 & 48.38 & 0.023 & 0.445 & 0.678 \\
\hline
\end{tabular}

SEM - standard error of the mean; DM - dry matter; EE - ether extract.

${ }^{1} \mathrm{CO}$ - control; CHI - chitosan, addition of $2 \mathrm{~g} \mathrm{~kg}^{-1}$ diet DM of chitosan; WS - whole raw soybeans, diet containing $72 \mathrm{~g} \mathrm{~kg}^{-1} \mathrm{EE}$ on diet DM basis; CHI+WS - chitosan and whole raw soybeans, addition of $2 \mathrm{~g} \mathrm{~kg}^{-1}$ diet DM of chitosan and diet containing $72 \mathrm{~g} \mathrm{~kg}^{-1} \mathrm{EE}$.

${ }^{2}$ Effects of chitosan (CHI), whole raw soybeans (WS), and interaction between CHI and WS (INT).

$\mathrm{a}-\mathrm{c}$ - values in the same row with a different letter differ significantly at $\mathrm{P} \leq 0.05$ according to the PDIFF test.

Table 5 - Nitrogen compounds of Jersey heifers fed chitosan and whole raw soybeans

\begin{tabular}{|c|c|c|c|c|c|c|c|c|}
\hline \multirow{2}{*}{ Item } & \multicolumn{4}{|c|}{ Diet $^{1}$} & \multirow{2}{*}{ SEM } & \multicolumn{3}{|c|}{ P-value ${ }^{2}$} \\
\hline & $\mathrm{CO}$ & $\mathrm{CHI}$ & WS & $\mathrm{CHI}+\mathrm{WS}$ & & CHI & WS & INT \\
\hline \multicolumn{9}{|l|}{ Urine $\left(\mathrm{mg} \mathrm{dL}^{-1}\right)$} \\
\hline Creatinine & 4.23 & 3.98 & 3.35 & 5.00 & 0.36 & 0.167 & 0.845 & 0.100 \\
\hline Urea nitrogen & 58.54 & 58.54 & 56.56 & 55.16 & 1.21 & 0.553 & 0.060 & 0.453 \\
\hline Creatinine nitrogen & 1.57 & 1.48 & 1.24 & 1.85 & 0.13 & 0.167 & 0.845 & 0.100 \\
\hline Creatinine & 0.77 & 0.80 & 0.53 & 0.78 & 0.04 & 0.008 & 0.012 & 0.182 \\
\hline Urea nitrogen & 18.81 & 16.54 & 20.09 & 19.74 & 1.07 & 0.023 & 0.001 & 0.100 \\
\hline Creatinine nitrogen & 0.28 & 0.29 & 0.20 & 0.29 & 0.01 & 0.008 & 0.012 & 0.182 \\
\hline \multicolumn{9}{|c|}{ Excretion (mg kg of $\mathrm{LW}^{-1}$ ) } \\
\hline Urea & 506.15 & 485.90 & 451.46 & 443.31 & 27.11 & 0.602 & 0.057 & 0.662 \\
\hline Creatinine & 30.52 & 30.56 & 30.52 & 30.52 & 0.07 & 0.192 & 0.207 & 0.112 \\
\hline \multicolumn{9}{|l|}{ Fractional excretion (\%) } \\
\hline Urea & 30.91 & 36.18 & 20.09 & 26.78 & 1.96 & 0.003 & 0.001 & 0.652 \\
\hline
\end{tabular}

SEM - standard error of the mean; LW - live weight; DM - dry matter; EE - ether extract.

${ }^{1} \mathrm{CO}$ - control; CHI - chitosan, addition of $2 \mathrm{~g} \mathrm{~kg}^{-1}$ diet DM of chitosan; WS - whole raw soybeans, diet containing $72 \mathrm{~g} \mathrm{~kg}^{-1} \mathrm{EE}$ on diet DM basis; CHI+WS - chitosan and whole raw soybeans, addition of $2 \mathrm{~g} \mathrm{~kg}^{-1}$ diet DM of chitosan and diet containing $72 \mathrm{~g} \mathrm{~kg}^{-1} \mathrm{EE}$.

${ }^{2}$ Effects of chitosan (CHI), whole raw soybeans (WS), and interaction between CHI and WS (INT).

Table 6 - Blood metabolites of Jersey heifers fed chitosan and whole raw soybeans

\begin{tabular}{|c|c|c|c|c|c|c|c|c|}
\hline \multirow{2}{*}{ Item } & \multicolumn{4}{|c|}{ Diet $^{1}$} & \multirow{2}{*}{ SEM } & \multicolumn{3}{|c|}{ P-value ${ }^{2}$} \\
\hline & $\mathrm{CO}$ & $\mathrm{CHI}$ & WS & $\mathrm{CHI}+\mathrm{WS}$ & & $\mathrm{CHI}$ & WS & INT \\
\hline Glucose $\left(\mathrm{mg} \mathrm{dL}^{-1}\right)$ & 98.68 & 96.01 & 93.15 & 99.32 & 5.39 & 0.771 & 0.657 & 0.667 \\
\hline Triacylglycerol (mg dL $\left.{ }^{-1}\right)$ & 50.25 & 51.12 & 30.12 & 49.12 & 7.83 & 0.547 & 0.349 & 0.407 \\
\hline Total cholesterol $\left(\mathrm{mg} \mathrm{dL}^{-1}\right)$ & 91.25 & 78.12 & 131.25 & 110.12 & 13.51 & 0.001 & 0.001 & 0.334 \\
\hline HDL & $28.00 \mathrm{~b}$ & $23.75 \mathrm{c}$ & $32.87 b$ & $46.37 \mathrm{a}$ & 3.60 & 0.367 & 0.099 & 0.006 \\
\hline LDL & 53.20 & 44.15 & 92.35 & 53.92 & 11.19 & 0.002 & 0.004 & 0.426 \\
\hline VLDL & 10.05 & 10.22 & 6.02 & 9.82 & 1.56 & 0.227 & 0.329 & 0.327 \\
\hline
\end{tabular}

SEM - standard error of the mean; DM - dry matter; EE - ether extract.

HDL - high-density lipoprotein; LDL - low-density lipoprotein; VLDL - very-low density lipoprotein.

${ }^{1} \mathrm{CO}$ - control; CHI - chitosan, addition of $2 \mathrm{~g} \mathrm{~kg}^{-1}$ diet DM of chitosan; WS - whole raw soybeans, diet containing $72 \mathrm{~g} \mathrm{~kg}{ }^{-1} \mathrm{EE}$ on diet DM basis; CHI+WS - chitosan and whole raw soybeans, addition of $2 \mathrm{~g} \mathrm{~kg}^{-1}$ diet DM of chitosan and diet containing $72 \mathrm{~g} \mathrm{~kg}^{-1} \mathrm{EE}$.

${ }^{2}$ Effects of chitosan (CHI), whole raw soybeans (WS), and interaction between CHI and WS (INT).

a-c - values in the same row with a different letter differ significantly at $\mathrm{P} \leq 0.05$ according to the PDIFF test. 


\section{Discussion}

Chitosan decreased the intakes of DM and NDF and increased DM total tract digestion (Table 2). Dry matter intake is a function of meal size and meal frequency, which are determined by dietary and animal factors that alter hunger and satiety (Allen, 2000). Decreased DM intake changes the ruminal nutrient passage, and the feed would be available for longer periods in the ruminal environment, increasing ruminal nutrient digestion. There is evidence that oxidizable fuels in the liver affect feed intake by transmission of information to the central nervous system via hepatic vagal afferents (Forbes, 1995; Allen et al., 2009). Animals fed chitosan probably had dry matter intake limited earlier than animals fed other diets due to the increase in DM digestibility and consequently a higher rate of oxidizable fuels reaching the liver. Among the fuels derived from the diet, propionate is most likely to promote oxidation during meals, mainly when high-concentrate diets are fed, because it can be produced fast and extracted from the blood by the liver, stimulating oxidation of acetyl CoA in the TCA cycle (Allen et al., 2009).

Although Araújo et al. (2015) reported a linear increase in $\mathrm{DM}, \mathrm{NDF}$, and $\mathrm{CP}$ digestibility when evaluating the dose effect of chitosan on the digestion of Nellore steers, the authors did not report differences in DM intake. The authors suggested that those effects were related to altered ruminal fermentation, especially by increasing the propionate concentration. Goiri et al. (2010) also reported that chitosan altered the ruminal fermentation pattern of sheep by increasing propionate proportion and decreasing the acetate to propionate ratio, without effects on DM intake.

Animals fed WS had a lower intake of NFC and increased intake of ether extract. Frequently, when supplemental fat is added to the diet, a source of NFC is withdrawn, and thus the EE content increases and the NFC content of the diet decreases. As there was no effect on DMI when cows received treatment WS, heifers increased their EE intake and decreased their NFC intake.

The results of nitrogen balance suggest better nitrogen utilization, due to greater retained nitrogen when animals were fed diets containing WS compared with CO. Whole raw soybeans partially replaced soybean meal; thus, the protein profile of $\mathrm{CO}$ and WS differed in rumen degradable protein values. However, no differences were found in microbial protein flow when cows were fed diets containing WS. High-concentrate diets may affect the efficiency of microbial protein synthesis due to decrease in ruminal $\mathrm{pH}$ (Strobel and Russell, 1986). Thus, the results of retained nitrogen may be related to the energy balance, which increased when cows were fed WS. The excess nitrogen in the blood of cows fed $\mathrm{CHI}$ or $\mathrm{CO}$ was excreted in urine because their net energy intake was lower than that of cows fed WS. VandeHaar (1998) proposed that dietary protein to energy ratios are an important factor in replacement-heifer diets, because an increase in dietary energy density may accelerate heifer growth, leading to an increase in the body protein deposition rate.

Chitosan decreased microbial protein synthesis, and this fact can be associated with its antimicrobial activity. Chitosan exerts greater bactericidal effects against gram-positive than gram-negative bacteria, and antimicrobial activity is enhanced at low $\mathrm{pH}$ values (Senel and McClure, 2004). The positive charges of chitosan influence the negative charges of the bacterial cell surface, due to competition with $\mathrm{Ca}^{+}$for electronegative sites on the membrane without conferring dimensional stability, rendering the membrane leaky (Begin and Calsteren, 1999). Increased propionate production is partially explained by the replacement with gram-negative instead of gram positive bacteria (Russel, 1987).

Monensin in several studies reduced ruminal protein degradation and consequently decreased microbial protein flow to the small intestine (Poos et al., 1979; Bergen and Bates, 1984). The decrease in ruminal ammonia production when monensin is supplied can be attributed to inhibitory effects on hyper-ammonia-producing bacteria (Eschenlauer et al., 2002) which have peptidase and deaminase activities (Wallace et al., 1997). Chitosan may have the same effect of monensin in ruminal protein degradation. Furthermore, $\mathrm{CHI}$ decreased blood urea concentrations and increased blood creatinine concentrations. The decreased blood concentration of urea can be related to altered ruminal protein degradation, which can reduce the production of ammonia and consequently decrease its absorption and liver metabolism to produce urea.

Creatinine excretion is not greatly affected by changes in diet, and variations in the daily creatinine excretion may be different according to the growth rate of animals (Chizzotti et al., 2008). Creatinine is raised from the muscle metabolism trough the clearance of creatinine phosphate (Harper et al., 1982). Thus, the increase in creatinine excretion by animals fed $\mathrm{CHI}$ is related to their higher live weight gain as compared with those fed $\mathrm{CO}$ (875.0 and $560.0 \mathrm{~g} \mathrm{~d}^{-1}$, respectively, data not shown).

Chitosan decreased and WS increased total cholesterol of heifers. Fat supplementation increases lipoprotein cholesterol export by the intestine, the major site of cholesterol synthesis in ruminants (Noble, 1981). Cônsolo et al. (2015) fed increasing doses of WS to Nellore bulls and found a linear increase in total cholesterol and no difference 
in glucose concentrations. The mechanism by which $\mathrm{CHI}$ alters the cholesterol metabolism is unclear, but studies in humans have demonstrated that chitosan reduced serum LDL cholesterol (Yihua and Binglin, 1997; Wuolijoki et al., 1999), and Bokura and Kobayashi (2003) suggested a reduced lipid absorption from the gastrointestinal tract. However, the difference between EE digestion between $\mathrm{CO}$ and CHI was only $13 \mathrm{~g} \mathrm{~kg}^{-1}$ in the current study.

\section{Conclusions}

Chitosan improves nutrient digestion and decreases dry matter intake and consequently reduces nitrogen excreted in feces. Whole raw soybean positively affects the energy intake and nitrogen utilization, compared with control or chitosan. Chitosan and whole raw soybeans do not alter nutrient intake and total tract digestion; however, they decrease nitrogen urinary excretion and increase blood HDL cholesterol of heifers.

\section{References}

Allen, M. S. 2000. Effects of diet on short-term regulation of feed intake by lactating dairy cattle. Journal of Dairy Science 83:1598-1624.

Allen, M. S.; Bradford, B. J. and Oba, M. 2009. Board invited review: the hepatic oxidation theory of the control of feed intake and its application to ruminants. Journal of Animal Science 87:3317-3334.

Araújo, A. P. A.; Venturelli, B. C.; Santos, M. C. B.; Gardinal R.; Cônsolo, N. R. B.; Calomeni, G. D.; Freitas Júnior, J. E.; Barletta, R. V.; Gandra, J. R.; Paiva, P. G. and Rennó, F. P. 2015. Short communication: Chitosan affects total nutrient digestion and ruminal fermentation in Nellore steers. Animal Feed Science and Technology 206:114-118.

AOAC - Association of Official Analytical Chemistry. 2000. Official methods of analysis 17th ed. AOAC International, Arlington, VA.

Begin, A. and Calsteren, M. R. V. 1999. Antimicrobial films produced from chitosan. International Journal of Biological Macromolecules 26:63-67.

Bergen, W. G. and Bates, D. B. 1984. Ionophores: Their effect on production efficiency and mode of action. Journal of Animal Science 58:1465-1483.

Bokura, H. and Kobayashi, S. 2003. Chitosan decreases total cholesterol in women a randomized, double-blind, placebocontrolled trial. European Journal of Clinical Nutrition 57:721-725.

Chen, X. B. and Gomes, M. J. 1992. Estimation of microbial protein supply to sheep and cattle based on urinary excretion of purine derivatives - an overview of technical details. (Occasional publication). International Feed Research Unit; Rowett Research Institute, Bucksburnd, Aberdeen. 21p.

Chizzotti, M. L.; Valadares Filho S. C.; Valadares, R. F. D.; Chizotti, F. H. M. and Tedeschi, L. O. 2008. Determination of creatinine excretion and evaluation of spot urine sampling in Holstein cattle. Livestock Science 113:218-225.

Cônsolo, N. R.; Gardinal, R.; Gandra, J. R.; Freitas Júnior, J. E.; Rennó, F. P.; Santana M. H.; Pflanzer Júnior, S. B. and Pereira, A. S. 2015. High levels of whole raw soybean in diets for Nellore bulls in feedlot: effect on growth, performance, carcass traits and meat quality. Journal of Animal Physiology and Animal Nutrition 99:201-209.

Eschenlauer, S. C.; McKain, N.; Walker, N. D.; McEwan, N. R.; Newbold, C. J. and Wallace, R. J. 2002. Ammonia production by ruminal microorganisms and enumeration, isolation, and characterization of bacteria capable of growth on peptides and amino acids from the sheep rumen. Applied and Environmental Microbiology 68:4925-4931.

Forbes, J. M. 1995. Voluntary food intake and diet selection in farm animals. CAB International, Oxon, UK.

Fujihara, T.; Orskov, E. R.; Reeds, P. J. and Kyle, D. J. 1987. The effect of protein infusion on urinary excretion of purine derivatives in ruminants nourished by intragastric nutrition. Journal of Agricultural Science 109:7-12.

Goiri, I.; Garcia-Rodriguez, A. and Oregui, L. M. 2009. Effects of chitosans on in vitro rumen digestion and fermentation of maize silage. Animal Feed Science and Technology 148:276-287.

Goiri, I.; Oregui, M. and Garia-Rodriguez. 2010. Use of chitosans to modulate ruminal fermentation of a 50:50 forage-to-concentrate diet in sheep. Journal of Animal Science 88:749-755.

González-Ronquillo, M.; Balcells, J. and Guada, J. A. 2003. Purine derivative excretion in dairy cows: endogenous excretion and the effect of exogenous nucleic acid supply. Journal of Dairy Science $86: 1282-1291$.

Hall, M. B. 1998. Making nutritional sense of nonstructural carbohydrate. p.108-121. In: Annual Florida Ruminant Nutrition Symposium. Florida University, Gainesville.

Harper, H. A.; Rodwell, V. W. and Mayes, P. A. 1982. Manual de química fisiológica. 5.ed. Atheneu, São Paulo.

Harvatine, K. J. and Allen, M. S. 2006. Effects of fatty acid supplements on milk yield and energy balance of lactating dairy cows. Journal of Dairy Science 89:1081-1091.

Hoffman, P. C.; Simson, C. R. and Wattiaux, M. M. 2007. Limit feeding of gravid Holstein heifers: effect on growth, manure nutrient excretion, and subsequent early lactation performance. Journal of Dairy Science 90:946-954.

NRC - National Research Council. 2001. Nutrient requirements of dairy cattle. 7th rev. ed. National Academy of Sciences, Washington, DC.

Noble, R. C. 1981. Digestion, transport and absorption of lipids. p.57-93. In: Lipid metabolism in ruminant animals. Christie, W. W., ed. Pergamon Press Ltd., Oxford, UK.

Oliveira, A. S.; Valadares, R. F.; Valadares Filho, S. C.; Cecon, P. R.; Rennó, L. N.; Queiroz, A. C. and Chizzotti, M. L. 2001. Produção de proteína microbiana e estimativas das excreções de derivados de purinas e de uréia em vacas lactantes alimentadas com rações isoprotéicas contendo diferentes níveis de compostos nitrogenados não-protéicos. Revista Brasileira de Zootecnia 30:1621-1629.

Poos, M. I.; Hanson, T. L. and Klopfenstein, T. J. 1979. Monensin effects on diet digestibility, ruminal protein bypass and microbial protein synthesis. Journal of Animal Science 48:1516-1524.

Russell, J. B. 1987. A proposed mechanism of monensin action in inhibiting ruminal bacterial growth: effects on ion flux and protonmotive force. Journal of Animal Science 64:1519-1525.

Senel, S. and McClure, S. J. 2004. Potential applications of chitosan in veterinary medicine. Advanced Drug Delivery Review 56:1467-1480.

Strobel, H. J. and Russell, J. B. 1986. Effect of pH and energy spilling on bacterial protein synthesis by carbohydrate-limited cultures of mixed rumen bacteria. Journal of Dairy Science 69:2941-2947.

Valadares, R. F. D.; Broderick, G. A. and Valadares Filho, S. C. 1999. Effect of replacing alfafa with high moisture corn on ruminal protein synthesis estimated from excretion of total purine derivatives. Journal of Dairy Science 82:2686-2696. 
VandeHaar, M. J. 1998. Feeding heifers as a long term investment. p.1. In: Proc. Northwest Dairy Nutrition Short course. Washington State University, Pullman, WA, USA.

Venturelli, B. C.; Freitas Junior, J. E.; Takiya, C. S.; Araujo, A. P. C.; Santos, M. C. B.; Calomeni, G. D.; Gardinal, R.; Vendramini, T. H. A. and Renno, F. P., 2015. Total tract nutrient digestion and milk fatty acid profile of dairy cows fed diets containing different levels of whole raw soya beans. Journal of Animal Physiology and Animal Nutrition, doi: 10.1111/jpn.12297 (in press).
Yihua, Y. U. and Binglin, H. E. 1997. A new low density lipoprotein (LDL) adsorbent. Artificial Cells, Blood Substitutes and Immobilization Biotechnology 25:445-450.

Wallace, R. J.; Onodera, R. and Cotta, M. A. 1997. Metabolism of nitrogen-containing compounds. p.283-328. In: The rumen microbial ecosystem. Hobson, P. N. and Stewart, C. S., eds. Springer, London.

Woulijoki, E.; Hirvela, T. and Ylitalo, P. 1999. Decrease in serum LDL cholesterol with microcrystalline chitosan. Methods \& Finding in Experimental \& Clinical Pharmacology 21:357-361. 